\title{
PERANAN GURU SERTA TANTANGAN PROFESIONALISME GURU DI INDONESIA
}

\author{
Maya Yuniarti \\ Email: 1910128220001@mhs.ulm.id \\ Program Studi Pendidikan IPS Fakultas Keguruan dan Ilmu Pendidikan Universitas \\ Lambung Mangkurat Banjarmasin
}

\begin{abstract}
Abstrak
guru merupakan pendidik profesional dengan tugas utama mendidik, mengajar, membimbing, mengarakan, melatih, menilai,dan mengevaluasi peserta didik pada pendidikan anak usia dini jalur formal, pendidikan dasar dan pendidikan menengah. dalam hal ini profesi guru sangat berperan penting dalam proses belajar pembelajaran tentunya dalam pendidikan di sekolah, guru sebagai kunci keberhasilan untuk mencapai tujuan pendidikan dalam sebuah sekolah berada digenggaman seorang guru. Maka untuk itu menjalankan tugas dan profesinya, guru mempunyai suatu hak dan kewajiban yang tentunya harus dilaksanakan dan diperhatikan, Yang terdapat menurut Undang-undang No. 14 tahun 2005 tentang guru dan dosen yang mana di buat oleh undang-undang. Dalam tantangan guru sebagi profeional memiliki sebuah kemajuan pendidikan di indonesai untuk itu Profesionalisme guru tentunya sangat diperlukan untuk memajukan pendidikan Indonesia dikarena profesionalisme guru yang tentunya memiliki keahlian didalam bidang pendidkan. Maka dalam hal ini guru tentunya memiliki sebuah komponen kompetensi professional guru agar dapat disebut sebagai guru professional sehingga terdapat beberpa komponen.
\end{abstract}

\section{PENDAHULUAN}

Profesi secara etimologi berasal dari kata profession (inggris) yang berasal dari bahasa Latin profesus yang berarti “mampu atau ahli dalam suatu bentuk pekerjaan”. Profesi dapat diartikan sebagai suatu pekerjaan atau jabatan yang menuntut keahlian, yang didapat melalui pendidikan dan latihan tertentu, menurut persyaratan khusus memiliki tanggung jawab dan kode etik tertentu (Susanto, 2020: 13). Profesi adalah suatu pekerjaan atau jabatan yan menuntut keahlian tertentu. Maksudnya adalah pekerjaan atau jabatan yang disebut profesi tidak dapat dimiliki oleh sembarangan orang. Tetapi memerlukan persiapan melalui pendidikan dan pelatihan secara khusus (Musriadi, 2016: 27-30 dalam Susanto : 2020).

Maka profesi merupakam suatu pekerjaan tertentu yang memeiliki syarat khusus dan memiliki latar belakang pendidikan tinggi yang dapat meyakinkan kepercayaan seseorang yang memerlukannya maka dapat disebut sebgai profei atau pekerjaan profesional. Jadi suatu pekekrjaan atau jabatan yang disebut profesi tidak dipegang oleh sembarang orang. Dalam 
hal ini dapat diartikan bahwa profesi adalah suatu jabatan atau pekerjaan yang menekan pada keahlian tertetu dapat dibuktikan secara teruji dari parapeserta atau anggota yang memiliki pekekrjaan dalam bidang ahli tertentu. Bahwasanya profesi sebagai suatu pekerjaan tidak bisa dilakukan oleh sembarang orang yang tidak terlatih dan tidak disiapkan secara khusus untuk melakukan pekerjaan itu.

guru merupakan suatu pendidik yang dikatakan sebgai profesional yang memiliki sebuah tugas utama mendidik, mengajar, membimbing, mengarakan, melatih, menilai,dan mengevaluasi peserta didik pada pendidikan anak usia dini jalur formal, dalam pendidikan dasar dan pendidikan menengah. Maka dari itu guru dapat dikelompokan sebgai profesi merupakan suatu jabatan yang memerlukan keahlian dan pelatihan khusus sebagai guru dan tidak dapat dilakukan oleh sembarang orang diluar bidang pendidikan. Perlu kita ketahui guru adalah sebuah jabatan atau profesi yang memerlukan keahlian khusus untuk menjadi sebagai guru. Pekerjaan atau profesi tentu dapat dilakukan oleh sesorang yang tidak memiliki keahlian untuk melaksanakan kegiatan atau pekerjaan sebagai guru. Sehingga jika ingin menjadi guru diperlukan syarat-syarat tertentu, apalagi sebagai guru yang profesional yang tentunya harus menguasai betul-betul seluk beluk pendidikan dan pengajaran dengan berbagai ilmu pengetahuan lainnya yang perlu dikelola dan dikembangkan melalui masa pendidikan tertentu atau berdasrkan pendidikan pra-jabatan.

Maka profesi guru sangat berperan penting dalam proses belajar pembelajaran tentunya dalam pendidikan di sekolah, guru meliankan sebagai kunci keberhasilan untuk mencapai tujuan pendidikan dalam sebuah sekolah berada digenggaman seorang guru. Karena guru dapat membantu pertumbuhan, ketermpilan, kecerdasan dan perkembangan siswa menjadikan sebagai wrga Negara yang baik dan taat dalam aturan di masayrakat. Namun tidak hanya guru saja yang mempunyai pengaruh bagi baik tidaknya siswa, keluarga dan masyarakat juga punya andil dalam hal ini dalam tercapainya tujuan pendidikan. Dimana profesi guru memiliki posisi yang strategis bagi pemberdayaan dan pembelajaran suatu bangsa yang tidak memungkin digantika oleh profesi manapun dalam kehidupan sebuah bangasa sejak dahulu dimana profesi guru lah yang sangat tepat.

\section{PERAN GURU SEBAGAI SEBUAH PROFESI}

Guru dapat dikatakan sebuah profesi karena menjadi seorang guru dituntut suatu keahlian tertentu yaitu (mengajar, mengelola kelas, merancang pembelajaran) dan dari sebuah pekerjaan ini seseorang dapat memiliki nafkah bagi kehidupan. Maka guru merupakan dapat digolongkan/diklasifikasikan sebagai sebuah profesi karena dalam hal ini memili ciri-ciri seorang guru sebagai profesi adalah sebagai berikut.

Menurut Rickey (1987) sebagaimana dikutif Soetjipto dan Kosasi (2009: 17) mengemukakan ciri-ciri guru sebagai profesi, yaitu: 
1) Adanya komitmen dari para guru bahwa jabatan itu mengharuskan pengikutnya menjunjung tinggi martabat kemanusiaan lebih dari pada mencari keuntungan diri sendiri.

2) Suatu profesi mensyaratkan orangnya mengikuti persiapan profesional dalam jangka waktu tertentu.

3) Harus selalu menambah pengetahuan agar terus menerus berkembang dalam jabatannya.

4) Memiliki kode etik jabatan.

5) Memiliki kemampuan intelektual menjawab masalah-masalah yang dihadapi.

6) Selalu ingin belajar terus-menerus mengenai bidang keahlian yang ditekuni.

7) Menjadi anggota dari suatu organisasi profesi.

8) Jabatan itu dipandang sebagai suatu karir hidup.

Dalam hal ini guru golongkan sebagai propesi yaitu merupakan sebuah pekekrjaan yang mana memiliki sebuah keahlian kusus didalamnya denga tugas utama yaitu sebgai pengajar, membimbing, mengarakan, melatih, menilai,dan mengevaluasi peserta didik pada pendidikan anak usia dini jalur formal, dalam sebuah perkembangan peserta didik baik rohani dan jarmaninya.

Bedasarkan UU RI No.14 tahun 2005 tentang Guru dan Dosen Pasal 1, Guru adalah pendidik profesional dengan tugas utama mendidik, mengajar, membimbing, mengarahkan, melatih, menilai, dan mengevaluasi peserta didik pada pendidikan anak usia dini jalur pendidikan formal, pendidikan dasar, dan pendidikan menengah. Dosen adalah pendidik profesional dan ilmuan dengan tugas utama mentransformasikan, mengembangkan, dan menyebarluaskan ilmu pengetahuan, teknologi, dan seni melalui pendidikan, penelitian, dan pengabdian kepada masyarakat.(Susanto, 2020: 16).

Untuk hal ini untuk menjalankan tugas dan profesinya, guru mempunyai suatu hak dan kewajiban yang tentunya harus dilaksanakan dan diperhatikan. Maka Hak guru merupakan suatu yang tentunya didapatkan setiap guru setelah menjalankan sejumlah kewajibannya sebagai serang guru. Sedangakan Kewajiban guru merupakan sesuatu yang diharuskan untuk dilaksanakan oleh guru dalam menjalankan profesinya. Tentunya dalam hal ini hak dan kewaiban seorang gugru di lindungi dan diatur oleh undang-undang dengan berkaitan tentang pendidikan.

Berukut adalah UU No. 14 Tahun 2005 tentang guru dan dosen pada bagian kedua mengenai hak dan kewajiban pada pasal 14, adapun hak yang dimiliki oleh seorang guru sebagai berikut (Susanto, 2020: 44)

a. Memperoleh penghasilan di atas kebutuhan hidup minimum dan jaminan kesejahteraan sosial. 
b. Mendapatkan promosi dan penghargaan sesuai dengan tugas dan prestasi kerja.

c. Memperoleh perlindungan dalam melaksanakan tugas dan hak atas kekayaan intelektual.

d. Memperoleh kesempatan untuk meningkatkan kompetensi.

e. Memperoleh dan memanfaatkan sarana dan prasarana pembelajaran untuk menunjang kelancaran tugas keprofesionalan.

f. Memiliki kebebasan dalam memberikan penilaian dan ikut menentukan

g. kelulusan, penghargaan, dan atau sanksi kepada peserta didik sesuai dengan kaidah pendidikan, kode etik guru, dan peraturan perundang-undangan.

h. Memperoleh rasa aman dan jaminan keselamatan dalam melaksanakan tugas.

i. Memiliki kebebasan untuk berserikat dalam organisasi profesi

j. Memiliki kesempatan untuk berperan dalam penentuan kebijakan pendidikan.

k. Memperoleh kesempatan untuk mengembangkan dan meningkatkan kualifikasi akademik dan kompetensi.

Dalam melaksanakan tugas keprofesionalan dalam UU No. 14 tahun 2005 tentang guru dan dosen, pada pasal 20 maka guru berkewajiban sebagai berikut:

a. Merencanakan pembelajaran, melaksanakan proses pembelajaran yang bermutu, serta menilai dan mengevaluasi hasil pembelajaran.

b. Mengembangkan dan meningkatkan kualifikasi akademik dan kompetensi secara berkelanjutan sejalan dengan perkembangan ilmu pengetahuan, teknologi dan seni.

c. Bertindak objektif dan tidak diskriminatif atas dasar pertimbangan jenis kelamin, agama, suku, ras, dan kondisi fisik tertentu, atau latar belakang keluarga, dan status sosial ekonomi peserta didik dalam pembelajaran.

d. Menjunjung tinggi peraturan perundang undangan, hukum dan kode etik guru, serta nilai nilai agama dan etika.

e. Memelihara dan memupuk persatuan dan kesatuan bangsa.

Dari hak dan kewajiban guru dan dosen dalam undang-undang tersebut maka dapat diambil sebuah kesimpulan bahwa bahwasanya tugas dan kewajiabn seorang guru dan dosean tentunya dapat menjalankan hak merak sebgai guru untuk melaksnakan kewaiban sepagai pendidik. Sehingga denagan adanya perlindungan itu yang dibuat oleh undang-undang dapat membuat meraka merasa lebih aman dalam menjalankan sebuah pekekrjaan atau profesi dan dapat berkontribus dalam sebuah pendidikan untuk memajuakan pendidikan secara maksimal. 
Kemudian peranan peran seorang guru dicetuskan Ki Hadjar Dewantara "ing ngarso sung tulodo, ing madya mangun karso, tutwuri handayani" maka peran guru adalah sebagai: (Susanto, 2020: 38-39)

a. Role model (ing ngarso sung tulodo), memberikan teladan kepada siswa karena fungsi guru menjadi pemimpin siswa dalam kegiatan pembelajaran.

b. Motor penggerak (ing madya mangun karso), guru harus menjadi penggerak inovasi dalam proses pendidikan dan penggerak peradaban dengan cara mengarahkan siswa untuk melakukan yang benar.

c. Motivator (tutwuri handayani), mampu memberikan dorongan semangat kepada siswa untuk mengadapi setiap persoalan dan mempelajari nilai-nilai kehidupan.

Maka dalam hal ini peran guru yang dikemukakan oleh Ki Hadjar Dewantara bahwa dalam perananya guru memberikan teladan kepada peserta didik dikarenakan fungsi dan peran seorang guru menjadi pemimpin peserta didik dalam kegiatan pembelajaran. Kemudian, guru harus menjadi penggerak inovasi dalam proses pendidikan dan penggerak peradaban dengan cara mengarahkana peserta didik untuk melakukan yang benar serta guru mampu memberikan dorongan semangat kepada peserta didik untuk menghadapi setiap persoalan dan mempelajari nilai-nilai kehidupan. Kemudian guru juga harus menanamkan nilainilai kemanusisaan untuk menjadikan warga Negara yang yang baik dan bermoral.

\section{GURU INDONESIA DAN TANTANGAN PROFESIONALISME}

Secara leksikal, kata profesional mengarah pada profesionalisme. Dalam kamus besar bahasa Indonesia, profesionalisme mempunyai makna; mutu, kualitas, dan tindak tanduk yang merupakan ciri suatu profesi atau yang profesional. Profesionalisme merupakan sikap dari seorang profesional. Artinya sebuah term yang menjelaskan bahwa setiap pekerjaan hendaklah dikerjakan oleh seseorang yang mempunyai keahlian dalam bidangnya atau profesinya.(Susanto, 2020: 49)

Profesionalisme guru tentunya sangat diperlukan untuk memajukan pendidikan Indonesia dikarena profesionalisme guru yang tentunya memiliki keahlian didalam bidang pendidkan. Maka dimana hanya bisa dikerjakan oleh seseorang yang memang telah dipersiapkan atau dilatih untuk suatu pekerjaan tertentu terutama dalam memajukan pendidikan di Indonesia. Untuk hal ini guru sendiri tentunya berperan penting dalam sebuah keajauan pendidikan dimana seorang guru yang memiliki jiwa profesionalitas yang dapat diartikan bahwsanya memiliki sikap atau perilaku mental yang tentunya dapat memotivasi diri sebagai perwujudan dari guru professional dalam pembelajaran sebagai memajukan mutu pendiidakan. Sedangaka untuk keprofesionalismenya guru memiliki sebuah kemapuan dalam untuk melakukan sebuah pembelajaran yang efektif sebagai mengembangakan sebuah pendidikan. Diantaya adalah kemabpuan diman sebelum pembelajaran guru membuat 
rencana pembelajaran terlebih dahulu, kemudian Seorang guru tentunya ahli dalam bidang pengetahuan yang diajarkan dan ahli dalam tugas mendidik.

Komponen kompetensi yang harus dimiliki guru untuk dapat disebut sebagai guru professional yaitu adalah Menurut Cooper (1984:15) terbagi kedalam 4 komponen kompetensi dasar, yakni: (dikutip dalam Susanto, 2020: 51)

a. Mempunyai pengetahuan tentang belajar dan tingkah laku manusia

b. Mempunyai pengetahuan dan menguasai bidang studi yang dibinanya.

c. Mempunyai sikap yang tepat tentang diri sendiri, sekolah, teman sejawat dan bidang studi yang dibinanya

d. Mempunyai keterampilan dalam tekhnik mengajar

Sehingga guru harus memiliki kompetensi profesional dalam hal ini guru merupakan sebuah pendidik yang piawai dalam melaksanakan profesinya sehingga disebut sebagai guru yang kopeten dan profesional. karena kopetensi profesional merupakan kemapuan dasar yang tentunya harus dimiliki seorang guru. Dalam pembelajaran, yang terpenting adalah guru tentu memilki komprtensi profesioal merupakan kemampuan penguasaan materi pembelajaran secara luas dan mendalam yang memungkinkan guru dapat membimbing peserta didik untuk memenuhi standar kompetensi yang ditetapkan dalan Standar Nasional Pendidikan. Sebut misal, kemampuan perencanaan program proses belajar mengajar. Ketentuan lebih lanjut perihal kompetensi guru juga diatur dengan peraturan pemerintah.

\section{SIMPULAN}

Kesimpulan mengenai pembahsan diatas yaitu profesi merupakam suatu pekerjaan tertentu yang memeiliki syarat khusus dan memiliki latar belakang pendidikan tinggi yang dapat meyakinkan kepercayaan seseorang yang memerlukannya maka dapat disebut sebgai profei atau pekerjaan profesional. guru adalah sebuah jabatan atau profesi yang memerlukan keahlian khusus untuk menjadi sebagai guru. guru dapat dikelompokan sebgai profesi merupakan suatu jabatan yang memerlukan keahlian dan pelatihan khusus sebagai guru dan tidak dapat dilakukan oleh sembarang orang diluar bidang pendidikan. Kemudian Guru dapat dikatakan sebuah profesi karena menjadi seorang guru dituntut suatu keahlian tertentu yaitu (mengajar, mengelola kelas, merancang pembelajaran) dan dari sebuah pekerjaan ini seseorang dapat memiliki nafkah bagi kehidupan. peran, hak, dan kewajiban guru menurut Undang-undang No. 14 tahun 2005 tentang guru dan dosen telah dilindungi dan seta di cetus kan oleh undang-undang. Maka Hak guru merupakan suatu yang tentunya didapatkan setiap guru setelah menjalankan sejumlah kewajibannya sebagai serang guru. Sedangakan Kewajiban guru merupakan sesuatu yang diharuskan untuk dilaksanakan oleh guru dalam menjalankan profesinya. Tentunya dalam hal ini hak dan kewaiban seorang gugru di lindungi dan diatur oleh undang-undang dengan berkaitan tentang pendidikan. Selajutnya pada Profesionalisme guru tentunya sangat diperlukan untuk memajukan pendidikan Indonesia 
dikarena profesionalisme guru yang tentunya memiliki keahlian didalam bidang pendidkan. Dari 4 komponen kompotensi professional tentunya guru harus memiliki kompetensi profesional dalam hal ini guru merupakan sebuah pendidik yang piawai dalam melaksanakan profesinya sehingga disebut sebagai guru yang kopeten dan professional.

\section{REFERENSI}

Efendi, I., Prawitasari, M., \& Susanto, H. (2021). Implementasi Penilaian Pembelajaran Pada Kurikulum 2013 Mata Pelajaran Sejarah. Prabayaksa: Journal of History Education, 1(1), 21-25.

Susanto, H. (2020). Profesi Keguruan. Banjarmasin: FKIP Universitas Lambung Mangkurat.

Susanto, H., \& Akmal, H. (2018). Efektivitas Penggunaan Aplikasi Pembelajaran Berbasis Mobile Smartphone Sebagai Media Pengenalan Sejarah Lokal Masa Revolusi Fisik Di Kalimantan Selatan Pada Siswa Sekolah Menengah Atas. HISTORIA: Jurnal Program Studi Pendidikan Sejarah, 6(2), 197-206.

Susanto, H., Irmawati, I., Akmal, H., \& Abbas, E. W. (2021). Media Film Dokumenter Masuknya Islam Ke Nusantara dan Pengaruhnya Terhadap Keterampilan Berpikir Kritis Siswa. HISTORIA: Jurnal Program Studi Pendidikan Sejarah, 9(1).

Syaharuddin, S., \& Susanto, H. (2019). Sejarah Pendidikan Indonesia (Era Pra Kolonialisme Nusantara sampai Reformasi). Banjarmasin: FKIP Universitas Lambung Mangkurat.

Sholikah, S. (2017). ANALISIS UNDANG-UNDANG NO. 14 TAHUN 2005 TENTANG GURU DAN DOSEN (Sebuah Kajian Kritis). Akademika, 11(01) 